\title{
Induction of Growth Promotion and Resistance Against Downy Mildew on Pearl Millet (Pennisetum glaucum) by Rhizobacteria
}

\author{
S. Niranjan Raj, G. Chaluvaraju, K. N. Amruthesh, and H. S. Shetty, Department of Studies in Applied Botany \\ and Biotechnology, University of Mysore, Manasagangotri, Mysore, India 570006; and M. S. Reddy and Joseph \\ W. Kloepper, Department of Entomology and Plant Pathology, Alabama Agricultural Experiment Station, Auburn \\ University, Auburn 36849
}

\begin{abstract}
Niranjan Raj, S., Chaluvaraju, G., Amruthesh, K. N., Shetty, H. S., Reddy, M. S., and Kloepper, J. W. 2003. Induction of growth promotion and resistance against downy mildew on pearl millet (Pennisetum glaucum) by rhizobacteria. Plant Dis. 87:380-384.

A series of laboratory, greenhouse, and field experiments were conducted to evaluate seven strains of plant growth-promoting rhizobacteria (PGPR). The PGPR were tested as suspensions of fresh cultures and talc-based powder formulations. Evaluations were conducted on pearl millet (Pennisetum glaucum) for growth promotion and management of downy mildew caused by Sclerospora graminicola. All treatments with fresh suspensions and powdered formulations showed enhancement in germination and vigor index over the respective untreated controls. With fresh suspensions, maximum vigor index resulted from treatments by Bacillus pumilus strain INR7 followed by B. subtilis strain IN937b (64 and 38\% higher than the untreated control, respectively). With powdered formulation, treatment with strain INR7 also resulted in the highest germination and vigor indexes, which were 10 and 63\%, respectively, over the untreated control. Under experimental plot conditions, prominent enhancement in growth also was observed in the disease tests. Yield was enhanced 40 and $37 \%$ over the untreated control by seed treatment with powdered formulations of strains INR7 and SE34, respectively. The same strains also increased yield by 36 and 33\%, respectively, when applied as fresh suspensions. Studies on downy mildew management resulted in varied degrees of protection by the PGPR both under greenhouse and field conditions. With fresh suspensions, treatment with INR7 resulted in the highest protection (57\%), followed by B. pumilus strain SE34 and B. subtilis strain GBO3, which resulted in 50 and $43 \%$ protection, respectively, compared with the untreated control. With powdered formulation, PGPR strain INR7 suppressed downy mildew effectively, resulting in $67 \%$ protection, while SE34 resulted in 58\% protection, followed by GBO3 with 56\% protection. Treatment with Apron (Metalaxyl) resulted in the highest protection against downy mildew under both greenhouse and field conditions. Thus, the present study suggests that the tested PGPR, both as powdered formulations and fresh suspensions, can be used within pearl millet downy mildew management strategies and for plant growth promotion.
\end{abstract}

Plant growth-promoting rhizobacteria (PGPR) are free-living, root-colonizing bacteria that have beneficial effects on plants. They reduce disease severity and enhance yield of many crops $(6,8)$. Most work with PGPR has been done with biological control of soilborne diseases $(2,3)$. PGPR are potentially helpful components in biologically based pest management programs (17).

Pearl millet (Pennisetum glaucum) is one of the world's main coarse grain crops.

Corresponding author: M. S. Reddy

E-mail: mreddy@acesag.auburn.edu

This work has been carried out in the project on "Systemic Acquired Resistance" funded by the Danish International Development Agency under the Enhancement of Research Capacity Programme (DANIDA ENRECA).

Accepted for publication 7 November 2002.

Publication no. D-2003-0203-03R

(C) 2003 The American Phytopathological Society
It is an essential cereal crop that has been widely grown in arid and semi-arid regions in Africa and Asia since prehistoric times. It provides staple food and is cultivated in relatively dry tracts with poor soil fertility. It also is valued for its dry fodder in livestock-based farming systems, which are predominant in these regions. The crop is grown in India as a rainfed or irrigated crop on 11.8 million ha.

Among the diseases that reduce crop yield, downy mildew caused by the biotrophic oomycetous fungus Sclerospora graminicola (Sacc.) J. Schröt. is one of the most dangerous diseases. It causes an annual loss of up to $40 \%$, amounting to $\$ 270$ million annually (13). The available management strategies include use of resistant cultivars and systemic fungicides. However, the lack of durable resistance, existence of pathogenic variability, and concerns about fungicide resistance have limited the potential of such strategies for managing the disease. Hence, the present study was conducted to evaluate the effectiveness of seed treatment with fresh cul- tures or dried formulations of plant growth-promoting Bacillus spp. for management of downy mildew disease and promotion of growth of pearl millet.

\section{MATERIALS AND METHODS}

PGPR strains and inoculum preparation. Seven PGPR strains (Bacillus pumilus T4, B. pumilus INR7, B. amyloliquefaciens IN937a, Bacillus subtilis IN937b, B. pumilus SE34, Brevibacillus brevis IPC11, and B. subtilis GB03) were obtained from the culture collection of the Department of Entomology and Plant Pathology, Auburn University (Auburn, AL), for greenhouse tests and field trials. All of the selected PGPR strains have significantly reduced foliar disease following application as seed treatments on cucumber, tomato, and tobacco $(6,8,10,11,17,18)$. PGPR strains were stored in tryptic soy broth (TSB) (Difco Laboratories, Detroit, MI) amended with $20 \%$ glycerol at $-80^{\circ} \mathrm{C}$ prior to use. Bacterial cell suspensions were prepared by streaking PGPR strains from ultracold storage onto tryptic soy agar (TSA) (HiMedia), incubating at $27^{\circ} \mathrm{C}$ for $24 \mathrm{~h}$ to check for purity, and then transferring single colonies to TSA. After $24 \mathrm{~h}$, the bacterial cells were harvested from the TSA plates in sterile distilled water (SDW) and centrifuged at $6,000 \mathrm{rpm}$ for $5 \mathrm{~min}$. The pellet obtained was resuspended in SDW. The optical density of the suspension was adjusted using a UV visible spectrophotometer (Hitachi U-2000, Hitachi Instruments Inc., San Jose, CA) following the method of Mortensen (7) to obtain a final density of $10^{8} \mathrm{CFU} / \mathrm{ml}$.

Host. Seed of pearl millet cv. HB3, which is highly susceptible to $S$. graminicola, were obtained from the International Crop Research Institute for Semi-Arid Tropics (ICRISAT), Hyderabad, India and the All India Coordinated Pearl Millet Improvement Project, Mandor, Rajasthan, India.

Source of pathogen and inoculum preparation. Sclerospora graminicola was collected from pearl millet cv. HB3 grown under heavily infested field conditions (12). The pathogen was maintained on its susceptible host prior to use.

Leaves of pearl millet showing profuse sporulation of $S$. graminicola on the abaxial side were collected in the evening from the plants maintained under green- 
house conditions. Collected leaves were washed thoroughly under running tap water to remove existing sporangia. The leaves then were blotted dry, cut into small pieces, and kept in a moist chamber for sporulation. The next morning, the fresh crop of sporangia was harvested into distilled water. For use as inoculum, the zoospore concentration was adjusted to 40,000/ml using a haemocytometer.

Effect of PGPR on seedling germination and vigor of pearl millet under laboratory conditions. Seven PGPR strains were used as seed treatments as fresh suspensions and talc formulations. Assays were conducted separately for each formulation tested. For fresh suspensions, seed of HB3 were surface sterilized with $0.02 \%$ mercuric chloride for $5 \mathrm{~min}$ and rinsed thoroughly in SDW. Bacterization of the seed was achieved by soaking seeds in PGPR suspensions $(5 \mathrm{~g} / 25 \mathrm{ml})$, prepared as described earlier, and amended with $0.2 \%$ sterilized carboxymethyl cellulose (CMC) as a sticker. The suspensions were incubated at $26^{\circ} \mathrm{C}$ in a rotary shaker for $6 \mathrm{~h}$ to facilitate attachment of bacterial cells to the seed coat. Later, the seed were allowed to dry in an incubator at $30^{\circ} \mathrm{C}$. Seed treated with SDW amended with CMC served as an untreated control.

PGPR in a purified talc powder (14) formulation were prepared by aseptically mixing $400 \mathrm{ml}$ of the bacterial suspension, prepared as described above, with $1 \mathrm{~kg}$ of talc powder. This formulated mixture was mixed with $0.2 \%$ CMC prior to treating seed. Surface-sterilized seed of HB3 were mixed with the formulation at a rate of 10 $\mathrm{g} / \mathrm{kg}$ of seed. Seed treated with talc powder amended with CMC served as an untreated control.

Germination tests were carried out by the paper towel method (5) separately for fresh and talc formulations. PGPR-treated seed with fresh suspensions and talc formulations and controls were seeded onto paper towels. The brown germination paper was soaked in distilled water. Fifty seed were placed equidistant apart on the paper. Another presoaked paper towel was placed on the first one so that the seed were held in position. The towels were rolled with polythene wrapping to prevent drying of the towels, then incubated in an incubation chamber at $25 \pm 2^{\circ} \mathrm{C}$ for 7 days. The experiment consisted of four replications of 100 seed (50 seed in eight towels). After 7 days, the towels were unrolled and the number of seed germinated was counted and represented as a percentage. Seedling vigor was analyzed at the end of 7 days of incubation using the method of Baki and Anderson (1). To assess vigor, the length of the root and shoot of an individual seedling was measured. The vigor index (VI) was calculated using the formula VI $=$ (mean root length $\times$ mean shoot length) (percent germination). The experiment was conducted three times.
Effect of PGPR on growth promotion of pearl millet under greenhouse and field conditions. For the evaluation of growth promotion under greenhouse conditions, seed treated with PGPR fresh suspensions or powdered formulations were tested separately. Treated seed were sown in 10-cm-diameter plastic pots filled with $250 \mathrm{ml}$ of autoclaved soil and sand (2:1). There were seven PGPR treatments and an untreated control in each experiment. There were five replications per treatment and five pots per replication, with a single seed per pot. These were arranged in a randomized complete block design. Seed treated with sterile distilled water amended with CMC with and without talc served as untreated controls. Seedlings were maintained at 25 to $30^{\circ} \mathrm{C}$ with $95 \%$ relative humidity. Seedlings were watered daily and did not receive fertilization. At 30 days after seeding (DAS), seedling height, shoot fresh and dry weight, leaf surface area (automatic leaf analyzer, Licor-2100; ADC Bioscientific Ltd., Herts, England), and number of basal tillers per plant were measured. The experiments were conducted three times.

Field trials were designed to test the effect of seven PGPR strains separately as fresh suspensions and powdered formulations on the growth of pearl millet. Two trials were conducted in red loamy soil $(\mathrm{pH}$ 6.7) at the experimental plots of the Department of Studies in Applied Botany and Biotechnology, University of Mysore, Karnataka, India during Kharif season (June to October) in 2000 and 2001. In each trial, the treatments were the same as described above. PGPR-treated seed were hand sown with 100 to 150 seed and there were five replications per treatment. Each replication was a single row of $5 \mathrm{~m}$ in length. Treatments were arranged in a randomized complete block design. The field was maintained according to the pearl millet growing conditions and irrigated once every 15 days. No chemicals or fertilizers were used. At 60 DAS, plant height and leaf surface area were recorded. Days to $50 \%$ flowering, total number of panicles per plant, and length and girth of panicles subsequently were measured. Weight of 1,000 seed was determined according to the procedure of ISTA (5), and yield was calculated by the procedure of Williams and Singh (16) at the time of harvest.

Screening of PGPR for potential to elicit systemic protection against downy mildew in the greenhouse and under field conditions. PGPR were applied as seed treatments using fresh suspensions and powdered formulations as described above and were tested separately for downy mildew protection. Nontreated CMC with or without talc powder served as untreated controls. Seed treated with the systemic fungicide Apron at a concentration of $2 \mathrm{~g} / \mathrm{kg}$ served as a positive control. For the greenhouse study, treated seed were sown in plastic pots, as described above, containing a mixture of soil and sand at a 2:1 ratio. Each treatment consisted of five replications, with five pots per replication. Each pot contained a single seedling. Treatments were arranged as a randomized complete block design. Twoday-old seedlings were maintained in the greenhouse as described above. The emerging seedlings were challenge inoculated by whorl inoculation method with the zoospore suspension of $S$. graminicola at a concentration of $4 \times 10^{4}$ zoospores $/ \mathrm{ml}$ prepared as described earlier. In the whorl inoculation method, droplets of S. graminicola zoospores were dropped onto the leaf whorl formed by the emerging seedlings and allowed to flow down to the base. The challenge-inoculated plants were maintained under greenhouse conditions (90 to $95 \%$ relative humidity, 20 to $25^{\circ} \mathrm{C}$ temperature). Disease incidence was monitored by counting the number of plants that showed any one of the typical downy mildew symptoms, which consisted of sporulation on the abaxial leaf surface, chlorosis, stunted growth, or malformation of the panicles. The experiment was concluded at 60 days after sowing. The experiments were repeated two times.

Two field trials were designed to test the elicitation of induced resistance against downy mildew of pearl millet by PGPR. Trials were conducted in red loamy soil (pH 6.7) at Downy Mildew Nursery, Department of Studies in Applied Botany and Biotechnology, University of Mysore, Karnataka, India during Kharif season (June to October) in 2000 and 2001. PGPR treatments and the controls were the same as described above. The field site was infested naturally with oospores of $S$. graminicola and served as the source of primary inoculum. Additional inoculum was provided by the infector rows (four rows bordering each plot) that were sown 21 days prior to the planting of the test rows as described by Williams (15), which facilitated the continuous shower of zoospores. Each treatment consisted of five replications. Each replicated row was manually seeded with 100 to 150 seed. These treatments were arranged as a randomized complete block design. Thinning was done after 21 days to maintain a uniform number of plants per row and uniform distance between the plants. The crop was irrigated every 15 days. Disease incidence was determined by counting the number of plants that showed any one of the typical downy mildew symptoms. The experiment was terminated at 60 days after sowing.

Data analysis. Data from repeated experiments were combined for analysis because there were no significant experiment-treatment interactions for either greenhouse or field experiments. The data from each experiment (PGPR applied as fresh suspensions or powdered formula- 
tions) was subjected to arcsine transformation and analysis of variance (JMP Software; SAS Institute Inc., Cary, NC). The significance of effect of PGPR treatments was determined by the magnitude of the $F$ value $(P=0.05)$. Treatment means were separated by Duncan's multiple range test.

\section{RESULTS}

Effect of PGPR on seedling germination and vigor of pearl millet under laboratory conditions. Five of seven PGPR strains (SE34, INR7, IN937a, IN937b, and IPC11) as fresh suspensions or powdered formulations significantly $(P$ $=0.05$ ) enhanced germination rate of pearl millet seed under laboratory conditions compared with untreated controls (Table 1). Four strains (SE34, INR7, IN937a, and IN937b) as fresh suspensions and five strains (SE34, INR7, IN937a, IN937b, and GBO3) as powdered formulations signifi-

Table 1. Effect of seed treatment with fresh suspensions or talc formulations of plant growth-promoting rhizobacteria (PGPR) on seed germination and seedling vigor of pearl millet ${ }^{\mathrm{x}}$

\begin{tabular}{|c|c|c|c|c|}
\hline \multirow[b]{2}{*}{ Treatment } & \multicolumn{2}{|c|}{ Germination (\%) } & \multicolumn{2}{|c|}{ Vigor index } \\
\hline & Fresh $^{y}$ & Talc $^{\mathrm{z}}$ & Fresh $^{y}$ & Talc ${ }^{\mathrm{z}}$ \\
\hline Untreated control & $82 \mathrm{a}$ & $84 \mathrm{a}$ & $707 \mathrm{a}$ & $608 \mathrm{a}$ \\
\hline INR7 & $92 \mathrm{c}$ & $92 \mathrm{c}$ & $1,156 \mathrm{c}$ & $992 \mathrm{c}$ \\
\hline SE34 & $90 \mathrm{bc}$ & $90 \mathrm{~b}$ & $944 \mathrm{~b}$ & $878 \mathrm{~b}$ \\
\hline GBO3 & $84 \mathrm{ab}$ & $84 \mathrm{a}$ & $857 \mathrm{ab}$ & $828 \mathrm{~b}$ \\
\hline IN937b & $90 \mathrm{bc}$ & $90 \mathrm{~b}$ & $978 \mathrm{bc}$ & $947 \mathrm{~b}$ \\
\hline IPC11 & $88 \mathrm{~b}$ & $90 \mathrm{~b}$ & $739 \mathrm{~b}$ & $642 \mathrm{a}$ \\
\hline $\mathrm{T} 4$ & $84 \mathrm{ab}$ & $84 \mathrm{a}$ & $828 \mathrm{ab}$ & $668 \mathrm{a}$ \\
\hline IN937a & $90 \mathrm{bc}$ & $90 \mathrm{~b}$ & 964 bc & $869 \mathrm{~b}$ \\
\hline
\end{tabular}

$\bar{x}$ Values are means from three repeated experiments with four replications and 100 seed per replication in each experiment. Means followed by the same letter in a column do not differ significantly according to Duncan's multiple range test at $P=0.05$.

y Fresh suspensions: each PGPR was applied onto surface-sterilized seed by soaking for $6 \mathrm{~h}$ in bacterial suspension $\left(1.0 \times 10^{8} \mathrm{CFU} / \mathrm{ml}\right)$ amended with $0.2 \%$ methyl cellulose at a rate of $5 \mathrm{ml} / \mathrm{g}$ of seed prior to seeding.

z Talc formulations: surface-sterilized seed were treated with powdered formulations of PGPR amended with $0.2 \%$ methyl cellulose at a rate of $1 \mathrm{~g} / 100 \mathrm{~g}$ of seed prior to seeding, which resulted in $1.0 \times 10^{6} \mathrm{CFU} / \mathrm{seed}$.

Table 2. Effect of seed treatment with fresh suspensions of plant growth-promoting rhizobacteria (PGPR) on growth of pearl millet seedlings 30 days after seeding under greenhouse conditions ${ }^{\mathrm{y}}$

\begin{tabular}{lcccc}
\hline Treatment & Height $(\mathbf{c m})$ & $\begin{array}{c}\text { Shoot dry } \\
\text { weight/plant }(\mathbf{g})\end{array}$ & $\begin{array}{c}\text { Leaf surface } \\
\text { area }\left(\mathbf{c m}^{\mathbf{2}}\right)\end{array}$ & $\begin{array}{c}\text { No. of basal } \\
\text { tillers/plant }\end{array}$ \\
\hline Untreated control & $23.7 \mathrm{a}$ & $1.9 \mathrm{a}$ & $26.7 \mathrm{a}$ & $2.4 \mathrm{a}$ \\
INR7 & $34.2 \mathrm{e}$ & $3.2 \mathrm{~d}$ & $39.2 \mathrm{e}$ & $3.3 \mathrm{~d}$ \\
SE34 & $32.9 \mathrm{e}$ & $3.0 \mathrm{~cd}$ & $35.1 \mathrm{~d}$ & $3.1 \mathrm{~cd}$ \\
GBO3 & $28.5 \mathrm{c}$ & $2.5 \mathrm{abcd}$ & $31.3 \mathrm{bc}$ & $3.1 \mathrm{~cd}$ \\
IN937b & $30.7 \mathrm{~d}$ & $2.7 \mathrm{bcd}$ & $30.5 \mathrm{bc}$ & $3.0 \mathrm{bcd}$ \\
IPC11 & $28.6 \mathrm{c}$ & $2.7 \mathrm{bcd}$ & $32.7 \mathrm{~cd}$ & $3.0 \mathrm{bcd}$ \\
T4 & $26.3 \mathrm{~b}$ & $2.3 \mathrm{abc}$ & $28.0 \mathrm{ab}$ & $2.7 \mathrm{ab}$ \\
IN937a & $26.6 \mathrm{~b}$ & $2.1 \mathrm{ab}$ & $29.7 \mathrm{abc}$ & $2.9 \mathrm{bc}$
\end{tabular}

y Values are means from three repeated experiments with five replications and five plants per replication in each experiment. Means followed by the same letter in a column do not differ significantly according to Duncan's multiple range test at $P=0.05$.

${ }^{\mathrm{z}}$ Each PGPR was applied onto surface-sterilized seeds by soaking for $6 \mathrm{~h}$ in bacterial suspension $\left(1.0 \times 10^{8} \mathrm{CFU} / \mathrm{ml}\right)$ amended with $0.2 \%$ methylcellulose at a rate of $5 \mathrm{ml} / \mathrm{g}$ of seed prior to seeding.

Table 3. Effect of seed treatment with powdered formulations of plant growth-promoting rhizobacteria (PGPR) on growth of pearl millet 30 days after seeding under greenhouse conditions ${ }^{y}$

\begin{tabular}{lcccc}
\hline Treatment & Height $(\mathbf{c m})$ & $\begin{array}{c}\text { Shoot dry } \\
\text { weight/plant }(\mathbf{g})\end{array}$ & $\begin{array}{c}\text { Leaf surface } \\
\text { area }\left(\mathbf{c m}^{\mathbf{2}}\right)\end{array}$ & $\begin{array}{c}\text { No. of basal } \\
\text { tillers/plant }\end{array}$ \\
\hline Untreated control & $23.3 \mathrm{a}$ & $1.8 \mathrm{a}$ & $26.3 \mathrm{a}$ & $2.2 \mathrm{a}$ \\
INR7 & $32.5 \mathrm{~d}$ & $3.0 \mathrm{~d}$ & $37.3 \mathrm{e}$ & $3.2 \mathrm{~d}$ \\
SE34 & $31.9 \mathrm{~d}$ & $2.6 \mathrm{~cd}$ & $34.6 \mathrm{de}$ & $3.0 \mathrm{~cd}$ \\
GBO3 & $28.1 \mathrm{c}$ & $2.6 \mathrm{bcd}$ & $29.3 \mathrm{ab}$ & $3.1 \mathrm{~d}$ \\
IN937b & $28.5 \mathrm{c}$ & $2.5 \mathrm{ab}$ & $30.3 \mathrm{bc}$ & $3.1 \mathrm{~d}$ \\
IPC11 & $27.8 \mathrm{c}$ & $2.5 \mathrm{bcd}$ & $32.6 \mathrm{~cd}$ & $2.9 \mathrm{~cd}$ \\
T4 & $27.1 \mathrm{bc}$ & $2.1 \mathrm{abc}$ & $28.4 \mathrm{ab}$ & $2.4 \mathrm{ab}$ \\
IN937a & $26.1 \mathrm{~b}$ & $1.9 \mathrm{a}$ & $27.0 \mathrm{ab}$ & $2.8 \mathrm{bc}$ \\
\hline
\end{tabular}

$y$ Values are means from three repeated experiments with five replications and five plants per replication in each experiment. Means followed by the same letter in a column do not differ significantly according to Duncan's multiple range test at $P=0.05$.

${ }^{z}$ Surface-sterilized seed were treated with powdered formulations of PGPR amended with $0.2 \%$ methyl cellulose at a rate of $1 \mathrm{~g} / 100 \mathrm{~g}$ of seed prior to seeding, which resulted in $10^{6} \mathrm{CFU} / \mathrm{seed}$. cantly enhanced the VI compared with the untreated controls (Table 1). The highest germination and VI was obtained with INR7 in both application forms.

Effect of PGPR on growth promotion of pearl millet under greenhouse and field conditions. In general, all the PGPR tested as fresh suspensions and powdered formulations showed positive growth responses among all the parameters measured under greenhouse conditions compared with the nonbacterized controls. Specifically, all the strains significantly enhanced seedling height compared with the untreated control with or without powdered formulation (Tables 2 and 3). Similarly, all the strains except IN937a and T4 as fresh suspensions and IN937a as a powdered formulation significantly enhanced shoot fresh weight compared with the untreated control. Strains IN937a and T4 did not provide any response on shoot dry weight, leaf surface area, and number of basal tillers/plant regardless of the formulation used. There was no effect from GBO3 fresh suspensions on shoot dry weight and, as a powdered formulation, this strain did not affect leaf surface area.

In the field trials, all the strains tested as fresh suspensions or powdered formulation significantly enhanced seedling height, length of panicle, and grain yield. All strains reduced days to $50 \%$ flowering compared with the untreated controls (Tables 4 and 5). Similarly, all the strains, except T4 as fresh suspensions, significantly enhanced leaf surface area compared with the untreated control. Strain T4 showed no effect on total number of panicles/plant and girth of panicle, regardless of formulation. Strain IN937b did not provide any effect on total number of panicles in either formulation. Similarly, strain IN937a had no effect on girth of panicle. All of the strains, except T4 as powdered formulations, significantly enhanced thousand-seed weight compared with the untreated control.

Effect of seed treatment with PGPR on downy mildew under greenhouse conditions. Varied degrees of protection (ranging from 23 to 57\%) against downy mildew were induced by the different isolates when applied as seed treatments with both formulations. When the test bacteria were tested as fresh suspensions, the lowest disease incidence of 40.6 (57\% protection) resulted with strain INR7, followed by SE34 and GBO3, which resulted in 46.7 and $53.4 \%$ downy mildew (50 and $43 \%$ protection), respectively (Table 6). Among the powdered formulations, treatment with strain INR7 resulted in $44.6 \%$ downy mildew $(52 \%$ protection) followed by SE34 and IN937b with 51.9 and $59.4 \%$ downy mildew (44 and $37 \%$ protection), respectively. The lowest incidence of downy mildew (i.e., 11.3 and $11.7 \%$ ) occurred with treatment by Apron (Table 6). 
Effect of seed treatment with PGPR on downy mildew under field conditions. In both field trials, all PGPR treatments significantly reduced the incidence of downy mildew compared with the untreated control treatments. Fresh suspensions of PGPR strain INR7 resulted in $30.2 \%$ downy mildew incidence $(67 \%$ protection), strain SE34 resulted in $38.6 \%$ downy mildew incidence (58\% protection), and strain GBO3 resulted in $40.5 \%$ downy mildew incidence (56\% protection) (Table 6). Protection is defined as the amount of disease on the untreated control minus the amount of disease on the PGPR treatment. The same trend also was noticed with the powdered formulations. However, the protection resulting from treatment by the powdered formulations was less than with fresh suspensions. Powdered formulation of INR7 resulted in $36.6 \%$ downy mildew incidence (protection of $61 \%$ ), followed by SE34 and IN937b with 48.1 and 50.6\% downy mildew incidence (49 and $48 \%$ protection), respectively. Treatment with
Apron resulted in the lowest disease incidence of $12 \%$ (Table 6 ).

\section{DISCUSSION}

Our results demonstrated the efficiency of PGPR in promoting growth and inducing resistance to downy mildew in pearl millet under both greenhouse and field conditions. Test PGPR were evaluated as fresh suspension and talc formulations. Statistical analysis of the results of the studies for growth promotion effect under greenhouse and field conditions showed significant enhancement of growth parameters and downy mildew disease suppression, both under field conditions, in comparison with the untreated controls. All seven plant growth-promoting Bacillus spp. tested in the present study promoted the vegetative and reproductive growth of pearl millet. However, the efficiency varied significantly among the isolates. The growth-promoting effect was evident from the early growth stages, germination, and vigor. Subsequently, vegetative growth parameters, such as height, leaf area, and number of tillers, and reproductive growth parameters, such as number, length and girth of panicles, thousand-seed weight, and yield were enhanced significantly by PGPR treatments compared with the untreated controls, regardless of the formulation method. Most important was the advancement of flowering date by 4 to 5 days.

PGPR are well-known inducers of disease resistance and some strains are effective against a broad spectrum of plant pathogens in a number of crop species. In the present study, all the bacterial strains tested reduced the incidence of downy mildew disease. Among the seven strains of Bacillus, two strains of Bacillus pumilus and two strains of $B$. subtilis showed significantly higher levels of disease suppression. Strains INR7 and SE34 of B. pumilus were unique in that, apart from showing the greatest reduction of disease incidence, they also were the best growth promoters. Their performance in growth promotion

Table 4. Effect of seed treatment with fresh suspensions of plant growth-promoting rhizobacteria (PGPR) on seedling growth, days to flowering, and yield of pearl millet under field conditions ${ }^{t}$

\begin{tabular}{|c|c|c|c|c|c|c|c|c|}
\hline Treatment $^{\mathrm{u}}$ & Height (cm) & $\begin{array}{l}\text { Leaf surface } \\
\text { area }\left(\mathrm{cm}^{2}\right)\end{array}$ & $\begin{array}{c}\text { No. of days } \\
\text { to } 50 \% \\
\text { flowering }\end{array}$ & $\begin{array}{c}\text { Total no. of } \\
\text { panicles per } \\
\text { plant }^{\mathrm{v}}\end{array}$ & $\begin{array}{c}\text { Length of } \\
\text { panicle }(\mathrm{cm})^{w}\end{array}$ & $\begin{array}{c}\text { Girth of } \\
\text { panicle }(\mathbf{c m})^{x}\end{array}$ & $\begin{array}{c}\text { Thousand- } \\
\text { seed weight } \\
(\mathrm{g})^{\mathrm{y}}\end{array}$ & $\begin{array}{c}\text { Yield } \\
(\mathbf{k g} / \mathbf{h a})^{z}\end{array}$ \\
\hline Untreated control & $89.4 \mathrm{a}$ & $92.0 \mathrm{a}$ & $49 \mathrm{a}$ & $4.5 \mathrm{a}$ & $8.4 \mathrm{a}$ & $4.7 \mathrm{a}$ & $5.3 \mathrm{a}$ & $1,124 \mathrm{a}$ \\
\hline INR7 & $124.2 \mathrm{f}$ & $125.9 \mathrm{f}$ & $45 \mathrm{~b}$ & $5.7 \mathrm{~d}$ & $12.7 \mathrm{~d}$ & $5.4 \mathrm{bcd}$ & $7.3 \mathrm{c}$ & $1,571 \mathrm{~g}$ \\
\hline SE34 & $120.2 \mathrm{e}$ & $122.6 \mathrm{de}$ & $45 \mathrm{~b}$ & $5.6 \mathrm{~cd}$ & $12.5 \mathrm{~d}$ & $5.4 \mathrm{bcd}$ & $7.1 \mathrm{c}$ & $1,538 \mathrm{f}$ \\
\hline GBO3 & $112.1 \mathrm{~cd}$ & $118.6 \mathrm{~d}$ & $45 \mathrm{e}$ & $4.6 \mathrm{a}$ & $12.4 \mathrm{~d}$ & $5.1 \mathrm{abcd}$ & $7.0 \mathrm{c}$ & $1,430 \mathrm{~d}$ \\
\hline IN937b & $112.4 \mathrm{~d}$ & $110.0 \mathrm{c}$ & $45 \mathrm{~d}$ & $5.0 \mathrm{abc}$ & $12.1 \mathrm{~cd}$ & $5.5 \mathrm{~cd}$ & $7.0 \mathrm{c}$ & $1,497 \mathrm{e}$ \\
\hline IPC11 & $104.6 \mathrm{bcd}$ & $101.8 \mathrm{~b}$ & $47 \mathrm{f}$ & $5.3 \mathrm{bcd}$ & $11.8 \mathrm{~cd}$ & $5.6 \mathrm{~d}$ & $6.5 \mathrm{c}$ & $1,396 \mathrm{c}$ \\
\hline $\mathrm{T} 4$ & $97.8 \mathrm{~b}$ & $98.8 \mathrm{ab}$ & $47 \mathrm{~g}$ & $4.9 \mathrm{ab}$ & $10.6 \mathrm{~b}$ & $4.9 \mathrm{ab}$ & $5.9 \mathrm{~b}$ & $1,306 \mathrm{~b}$ \\
\hline IN937a & $103.5 \mathrm{bc}$ & $103.9 \mathrm{bc}$ & $45 \mathrm{c}$ & $5.5 \mathrm{bcd}$ & $11.3 \mathrm{bc}$ & 4.9 abc & $6.0 \mathrm{~b}$ & $1,312 b$ \\
\hline
\end{tabular}

${ }^{\mathrm{t}}$ All the values are means from two repeated experiments with five replications per treatment. Means followed by the same letter in a column do not differ significantly according to Duncan's multiple range test at $P=0.05$.

u Each PGPR was applied onto surface-sterilized seed by soaking for $6 \mathrm{~h}$ in fresh bacterial suspension $\left(1.0 \times 10^{8} \mathrm{CFU} / \mathrm{ml}\right)$ amended with $0.2 \% \mathrm{methyl}$ cellulose at a rate of $5 \mathrm{ml} / \mathrm{g}$ of seed prior to seeding.

${ }^{v}$ Number of panicles produced by the main axis and the basal tillers of the plant.

${ }^{w}$ Measured from the base to the tip of the panicle.

${ }^{x}$ Measured as the circumference of the panicle at the center.

y Calculated by weighing 1,000 seed in five replicates.

${ }^{\mathrm{z}}$ Based on the weight of seeds collected from the central two rows and converting it into 1 ha.

Table 5. Effect of seed treatment with plant growth-promoting rhizobacteria (PGPR) formulated in talc powder on seedling growth, days to flowering, and yield of pearl millet under field conditions ${ }^{t}$

\begin{tabular}{|c|c|c|c|c|c|c|c|c|}
\hline Treatment $^{\mathrm{u}}$ & Height (cm) & $\begin{array}{c}\text { Leaf surface } \\
\text { area }(\mathrm{cm})\end{array}$ & $\begin{array}{c}\text { No. of days } \\
\text { to } 50 \% \\
\text { flowering }\end{array}$ & $\begin{array}{c}\text { Total no. of } \\
\text { panicles per } \\
\text { plant }^{\mathbf{v}}\end{array}$ & $\begin{array}{c}\text { Length of } \\
\text { panicle }(\mathrm{cm})^{\mathrm{w}}\end{array}$ & $\begin{array}{c}\text { Girth of } \\
\text { panicle }(\mathbf{c m})^{x}\end{array}$ & $\begin{array}{c}\text { Thousand- } \\
\text { seed weight } \\
(\mathrm{g})^{\mathrm{y}}\end{array}$ & $\begin{array}{c}\text { Yield } \\
(\mathbf{k g} / \mathbf{h a})^{z}\end{array}$ \\
\hline Untreated control & $87.4 \mathrm{a}$ & $87.4 \mathrm{a}$ & $49 \mathrm{a}$ & $4.3 \mathrm{a}$ & $8.4 \mathrm{a}$ & $4.6 \mathrm{a}$ & $5.1 \mathrm{a}$ & $1,120 \mathrm{a}$ \\
\hline INR7 & $117.9 \mathrm{f}$ & $121.2 \mathrm{~d}$ & $45 \mathrm{~b}$ & $5.6 \mathrm{~d}$ & $12.0 \mathrm{~cd}$ & $5.1 \mathrm{abc}$ & $7.1 \mathrm{~d}$ & $1,520 \mathrm{f}$ \\
\hline SE34 & $111.7 \mathrm{e}$ & $108.2 \mathrm{~d}$ & $45 \mathrm{~b}$ & $5.4 \mathrm{~cd}$ & $12.1 \mathrm{~cd}$ & $5.1 \mathrm{bc}$ & $7.0 \mathrm{~d}$ & 1,486 ef \\
\hline GBO3 & $108.0 \mathrm{~cd}$ & $109.6 \mathrm{c}$ & $45 \mathrm{e}$ & $5.5 \mathrm{~cd}$ & $13.7 \mathrm{~d}$ & $4.9 \mathrm{abc}$ & $6.9 \mathrm{~d}$ & $1,439 \mathrm{~d}$ \\
\hline IN937b & $107.3 \mathrm{~d}$ & $99.1 \mathrm{~b}$ & $45 \mathrm{~d}$ & $5.0 \mathrm{abc}$ & $11.7 \mathrm{bcd}$ & $5.2 \mathrm{bc}$ & $7.0 \mathrm{~d}$ & $1,460 \mathrm{de}$ \\
\hline IPC11 & $105.3 \mathrm{c}$ & $96.1 \mathrm{~b}$ & $47 \mathrm{f}$ & $5.1 \mathrm{bcd}$ & $11.7 \mathrm{bcd}$ & $5.4 \mathrm{~d}$ & $6.6 \mathrm{~cd}$ & $1,368 \mathrm{c}$ \\
\hline $\mathrm{T} 4$ & $97.3 \mathrm{c}$ & $99.5 \mathrm{~b}$ & $47 \mathrm{~g}$ & $4.5 \mathrm{ab}$ & $10.7 \mathrm{~b}$ & $4.8 \mathrm{ab}$ & $5.9 \mathrm{ab}$ & $1,303 \mathrm{~b}$ \\
\hline IN937a & $92.7 \mathrm{~b}$ & $96.0 \mathrm{~b}$ & $45 \mathrm{c}$ & $5.3 \mathrm{~cd}$ & $11.1 \mathrm{bc}$ & $5.1 \mathrm{abc}$ & $6.0 \mathrm{bc}$ & $1,337 \mathrm{bc}$ \\
\hline
\end{tabular}

${ }^{\mathrm{t}}$ All the values are means from two repeated experiments with five replications per treatment. Means followed by the same letter in a column do not differ significantly according to Duncan's multiple range test at $P=0.05$.

" Each PGPR was applied onto surface-sterilized seed by soaking for $6 \mathrm{~h}$ in fresh bacterial suspension $\left(1.0 \times 10^{8} \mathrm{CFU} / \mathrm{ml}\right)$ amended with $0.2 \% \mathrm{methyl}$ cellulose at a rate of $5 \mathrm{ml} / \mathrm{g}$ of seed prior to seeding.

${ }^{v}$ Number of panicles produced by the main axis and the basal tillers of the plant.

${ }^{w}$ Measured from the base to the tip of the panicle.

${ }^{x}$ Measured as the circumference of the panicle at the center.

y Calculated by weighing 1,000 seed in five replicates.

${ }^{\mathrm{z}}$ Based on the weight of seeds collected from the central two rows and converting it into 1 ha. 
Table 6. Effect of seed treatment with fresh suspensions or talc formulations of plant growth-promoting rhizobacteria (PGPR) on downy mildew incidence of pearl millet under greenhouse and field conditions

\begin{tabular}{|c|c|c|c|c|}
\hline \multirow[b]{3}{*}{ Treatment } & \multicolumn{4}{|c|}{ Downy mildew incidence $(\%)^{x}$} \\
\hline & \multicolumn{2}{|c|}{ Greenhouse } & \multicolumn{2}{|c|}{ Field } \\
\hline & Fresh $^{y}$ & Talc $^{z}$ & Fresh $^{y}$ & Talc $^{\mathbf{z}}$ \\
\hline Untreated control & $93.9 \mathrm{a}$ & $93.2 \mathrm{a}$ & $93.5 \mathrm{a}$ & $94.4 \mathrm{a}$ \\
\hline Apron & $11.3 \mathrm{e}$ & $11.7 \mathrm{f}$ & $12.0 \mathrm{~d}$ & $12.2 \mathrm{~h}$ \\
\hline INR7 & $40.6 \mathrm{~d}$ & $44.6 \mathrm{e}$ & $30.2 \mathrm{c}$ & $36.6 \mathrm{~g}$ \\
\hline SE34 & $46.7 \mathrm{~d}$ & $51.9 \mathrm{~d}$ & $38.6 \mathrm{bc}$ & $48.1 \mathrm{ef}$ \\
\hline GBO3 & $53.4 \mathrm{c}$ & $62.9 \mathrm{c}$ & $40.8 \mathrm{bc}$ & $53.1 \mathrm{de}$ \\
\hline IN937b & $55.0 \mathrm{c}$ & $59.4 \mathrm{~cd}$ & $47.5 \mathrm{~b}$ & $50.6 \mathrm{e}$ \\
\hline IPC11 & $60.5 \mathrm{~b}$ & $64.9 \mathrm{bc}$ & $42.2 \mathrm{bc}$ & $56.7 \mathrm{~d}$ \\
\hline $\mathrm{T} 4$ & $60.8 \mathrm{~b}$ & $67.3 \mathrm{~b}$ & $41.4 \mathrm{bc}$ & $62.5 \mathrm{c}$ \\
\hline IN937a & $65.3 \mathrm{~b}$ & $65.4 \mathrm{bc}$ & $49.5 \mathrm{~b}$ & $69.3 \mathrm{~b}$ \\
\hline
\end{tabular}

$x$ Percentage of downy mildew is the mean from two repeated experiments. Means followed by the same letter in a column do not differ significantly according to Duncan's multiple range test at $P=$ 0.05 .

y Fresh suspensions: each PGPR was applied onto surface-sterilized seed by soaking for $6 \mathrm{~h}$ in bacterial suspension $\left(1.0 \times 10^{8} \mathrm{CFU} / \mathrm{ml}\right)$ amended with $0.2 \%$ methylcellulose at a rate of $5 \mathrm{ml} / \mathrm{g}$ of seed prior to seeding.

z Talc formulations: surface-sterilized seed were treated with powdered formulations of PGPR amended with $0.2 \%$ methyl cellulose at a rate of $1 \mathrm{~g} / 100 \mathrm{~g}$ of seed prior to seeding, which resulted in $1.0 \times 10^{6} \mathrm{CFU} / \mathrm{seed}$

and disease suppression remained consistent under both greenhouse and field conditions as both fresh suspensions and powdered formulations, suggesting the efficiency of these isolates under varied conditions. Treatment with Apron resulted in the greatest reduction in disease incidence.

Although the mechanism of disease suppression was not studied in this project, the results suggest the possible operation of either antimicrobial activity or induction of resistance. This suggestion is based on earlier reports for this group of microorganisms in which either antagonistic action or induction of systemic resistance has been reported (9). A variety of substances produced by PGPR have been implicated in the mechanisms to limit the damage to plants by phytopathogens. These include siderophores, antibiotics, other small molecules, and a number of enzymes $(4,6)$.

The application of PGPR as seed treatments could prove to be a beneficial component of integrated pest management. These bacteria, apart from their action against pathogens, are good growth promoters, which is an added advantage for any practical agricultural system.

\section{ACKNOWLEDGMENTS}

We thank E. de Neergaard, the Principal Responsible Party of the DANIDA ENRECA project, for his cooperation during the study; and the Indian Council of Agricultural Research (ICAR), Government of India through All India Coordinated Pearl Millet Improvement Programme (AICPMIP), for the facilities provided.

\section{LITERATURE CITED}

1. Baki, A. A., and Anderson, J. D. 1973. Vigor determination in soybean seed by multiple criteria. Crop Sci. 13:630-633.

2. Barka, E. A., Belarbi, A., Hachet, C., Nowak, J., and Audran, J. C. 2000. Enhancement of in vitro growth and resistance to gray mold of Vitis vinifera co-cultured with plant growthpromoting rhizobacteria. FEMS Microbiol. Lett. 91-95.

3. Burdman, S., Turkevitch, E., and Okon, Y. 2000. Recent advances in the use of plant growth promoting rhizobacteria (PGPR) in agriculture. Pages 229-249 in: Microbial Interaction in Agriculture and Forestry. N. S. Subba Rao and Y. R. Dommergues, eds. Science Pub., London.

4. Chen. C., Belanger, R., Benhamou., N., and Paulitz, T. C. 2000. Defense enzymes induced in cucumber roots by treatment with plant growth promoting rhizobacteria (PGPR) and Pythium aphanideramatum. Physiol. Mol. Plant Pathol. 56:13-23.

5. ISTA 1993. Proceedings of the International Seed Testing Association, International Rules for Seed Testing. Seed Sci. Technol. 21:25-30.

6. Liu, L., Kloepper, J. W., and Tuzun, S. 1995.
Induction of systemic resistance in cucumber by plant growth promoting rhizobacteria: duration of protection and effect of host resistance on protection and root colonization. Phytopathology 85:1064-1068.

7. Mortensen, C. N. 1992. Seed Bacteriology Laboratory Guide. Danish Government Institute of Seed Pathology for Developing Countries. Copenhagen, Denmark.

8. Murphy, J. F., Zehnder, G. W., Schuster, D. J., Sikora, E. J., Polstan, J. E., and Kloepper, J. W. 2000. Plant growth-promoting rhizobacteria mediated protection in tomato against $T o$ mato mottle virus. Plant Dis. 84:779-784.

9. Pieterse, C. M. J., and Van Loon, C. 1999. Salicylic acid-independent plant defense pathways. Trends Plant Sci. 4:52-58.

10. Raupach, G. S., and Kloepper, J. W. 1998. Mixtures of plant growth-promoting rhizobacteria enhance biological control of multiple cucumber pathogens. Phytopathology 88:1158-1164.

11. Raupach, G. S., and Kloepper, J. W. 2000 Biocontrol of cucumber diseases in the field by plant growth-promoting rhizobacteria with and without methyl bromide fumigation. Plant Dis. 84:1073-1075.

12. Safeeulla, K. M. 1976. Biology and Control of the Downy Mildews of Pearl Millet, Sorghum and Finger Millet. Wesley Press, Mysore, India.

13. Shetty, S. A., Shetty, H. S., and Mathur, S. B. 1995. Downy Mildew of Pearl Millet. Technical Bulletin, Downy Mildew Research Laboratory, Department of Studies in Applied Botany, University of Mysore, Manasagangotri, Mysore, India.

14. Umesha, S., Dharmesh, S. M., Shetty. S. A., Krishnappa, M., and Shetty, H. S. 1998. Biocontrol of downy mildew disease of pear millet using Pseudomonas fluorescens. Crop Prot. 17:387-392.

15. Williams, R. J. 1984. Downy mildew of tropical cereals. Pages 1-103 in: Advances in Plant Pathology. D. S. Ingram and P. H. Williams, eds. Academic Press, London.

16. Williams, R. J., and Singh, S. J. 1981. Control of pearl millet downy mildew by seed treatment with metalaxyl. Ann. Appl. Bot. 97:262 268.

17. Zehnder, G. W., Yao, C., Murphy, J. F., Sikora, E. R., Kloepper, J. W., Schuster, D. J. and Polston, J. E. 1999. Microbe-induced resistance against pathogens and herbivores: Evidence of effectiveness in agriculture. Pages 335-355 in: Induced Plant Defenses Against Pathogens and Herbivores, Biochemistry, Ecology, and Agriculture. A. A. Agrawal, S. Tuzun, and E. Bent, eds. American Phytopathological Society Press, St. Paul, MN.

18. Zhang, S., Reddy, M. S., and Kloepper, J. W. 2002. Development of assays for assessing induced systemic resistance by plant growthpromoting rhizobacteria against blue mold of tobacco. Biol. Control 23:79-86. 